Evaluasi Pelaksanaan Praktik Menelusur ...(Sukirno, Mukhotib)

\title{
EVALUASI PELAKSANAAN PRAKTIK MENELUSUR LITERATUR (LITERATURE SEARCHING) PADA MAHASISWA PROGRAM STUDI PENDIDIKAN DOKTER ANGKATAN 2015/2016 DI PERPUSTAKAAN FAKULTAS KEDOKTERAN UNIVERSITAS GADJAH MADA
}

\author{
Sukirno, Mukhotib \\ Pustakawan Universitas Gadjah Mada Yogyakarta \\ skirno@yahoo.com
}

Fakultas Kedokteran UGM memulai sejarah baru dengan memberlakukan strategi pembelajaran, pendidikan belajar berdasarkan masalah. Pelaksanaan inovasi pendidikan menekankan pada pemberian sarana-sarana belajar peserta didik aktif mandiri, bebas dalam menggali dan mensitesis kompentensi ilmu, ketrampilan, sikap perilaku, kepribadian profesi, psikomotor, dan afektif. Melalui pendekatan ini mahasiswa diharapkan mampu memanfaatkan berbagai sumber belajar, termasuk web site. Satu diantara sarana untuk mendukung suksesnya inovasi pembelajaran di Fakultas Kedokteran Universitas Gadjah Mada adalah tersediannya sumber-sumber belajar yang memadai, yaitu ketersediaan referensi di perpustakaan. Perpustakaan Fakultas Kedokteran UGM secara langsung dilibatkan dalam proses pembelajaran bagi mahasiswa Program Studi IImu Kedokteran, yaitu dengan memberikan praktik menelusur literatur (literature searching) pada blok A.1. pada topik "Being a Medical Student and Locomotor System". Untuk itu guna mengetahui proses pelaksanaan praktek menelusur literature tersebut, maka dilakukan penelitian ini. Tujuan penelitian ini untuk mengevaluasi pelaksanaan praktek menelusur literatur (literature searching) pada mahasiswa Program Studi Pendidikan Dokter angkatan 2015/2016. Metode yang digunakan dalam penelitian ini adalah metode kuantitatif dengan populasi Mahasiswa Pendidikan Dokter angkatan 2015/2016 sebanyak 273, sedang yang menjadi sampel 100 mahasiswa. Variabel dalam penelitian ini, meliputi, (1) pemateri, (2) materi dan metode pelatihan, (3) waktu pelaksanaan, dan (4) manfaat. Hasil evaluasi praktik menelusur literatur berdasarkan penelitian ini dikategorikan baik dengan nilai rata-rata skor $86,17 \%$. Adapun rekomendasi penelitian ini adalah praktek menelusur literatur, penyampaian materi dibuat lebih menarik dan lebih interaktif dengan diperbanyak untuk praktik menelusur.

Kata Kunci: Evalusi, Penelusuran Literatur, Perpustakaan Fakultas Kedokteran UGM

\section{Pendahuluan}

Fakultas Kedokteran UGM memulai sejarah baru dengan memberlakukan strategi pembelajaran, pendidikan belajar berdasarkan masalah (Problem Based Learning) secara penuh bagi para mahasiswa. Pelaksanaan inovasi pendidikan menekankan pada pemberian suasana-sarana belajar peserta didik aktif mandiri, bebas dalam menggali dan mensitesis kompentensi ilmu, ketrampilan, sikap perilaku, kepribadian profesi, psikomotor, dan afektif. Dalam aspek kognitif, $P B L$ diharapkan mampu mengaktifkan priorknowledge meningkat, akan pengetahuan, terutama dalam diskusi kelompok kecil. Melalui pendekatan ini mahasiswa diharapkan mampu memanfaatkan berbagai sumber belajar, termasuk web site serta mampu melakukan integrasi berbagai subjek, hingga lebih relevan dengan praktek profesional yang akan mereka hadapi. Aspek afektif, dan PBL akan membawa mahasiswa merasa apa yang mereka pelajari erat kaitannya sebagai calon dokter, meningkatkan motivasi intrinsik yang kuat, dan mengembangkan team work lewat kelompok kecil. Secara psikomotor, $P B L$ akan meningkatkan kemampuan komunikasi interpersonal karena mahasiswa akan lebih terlatih, meningkatkan kemampuan problem solving, dan mahasiswa dibiasakan belajar mandiri menuju life-long study learning. Pendekatan inovasi pendidikan ini akan meningkatkan mahasiswa motivasi intrinsik kuat dan dibiasakan belajar 
secara mandiri. Teknik pembelajaran dengan integrasi pengajaran bagian-bagian di Fakultas Kedokteran UGM yang berdasarkan blok-blok.

Satu diantara sarana untuk mendukung susksesnya inovasi pembelajaran di Fakultas Kedokteran Universitas Gadjah Mada adalah tersediannya sumber-sumber belajar yang memadai, yaitu ketersediaan referensi di perpustakaan. Keterlibatan Perpustakaan Fakultas Kedokteran UGM dalam mendukung proses pembelajaran dengan menyediakan berbagai jenis koleksi yang dibutuhkan oleh mahasiswa, baik dalam format cetak maupun digital. Jenis koleksi tersebut, antara lain; buku, karya ilmiah, jurnal, CD/l, database online, dan lain-lain. Agar mahasiswa dapat memanfaatkan dan mengakses berbagai koleksi tersebut, maka Perpustakaan Fakultas Kedokteran UGM secara langsung dilibatkan dalam proses pembelajaran bagi mahasiswa Program Studi Ilmu Kedokteran. Bentuk keterlibatan secara langsung tersebut, yaitu dengan memberikan praktek menelusur literatur (literature searching) yang masuk pada blokA.1. pada topik "Being a Medical Student and Locomotor System". Kegiatan praktek tersebut diselenggarakan di Perpustakaan Fakultas Kedokteran UGM dan yang menyampaikan praktek tersebut adalah pustakawan.

Untuk mengetahui pelaksanaan praktek menelusur literatur tersebut, apakah sudah sesuai dengan kebutuhan mahasiswa Program Studi Pendidikan Dokter di FK UGM, maka dilakukan penelitian ini.

\section{Rumusan Masalah}

Mencermati latar belakang penelitian tersebut, maka rumusan masalah dalam penelitian ini adalah:

Bagaimana evaluasi pelaksanaan praktik menelusur literatur (literature searching) pada mahasiswa Program Studi Pendidikan Dokter Angkatan 2015/2016 di Perpustakaan Fakultas Kedokteran Universitas Gadjah Mada?

\section{Tujuan Penelitian}

1. Untuk mengevaluasi pelaksanaan praktik menelusur literatur (literature searching) pada mahasiswa Program Studi Pendidikan
Dokter angkatan 2015/2016 di Perpustakaan Fakultas Kedokteran Universitas Gadjah Mada.

2. Untukmendapatkan masukan darimahasiswa terhadap pelaksanaan praktik menelusur literatur (literature searching) yang dapat digunakan sebagai dasar kebijakan dalam pelaksanaan praktik literature searching.

3. Untuk mengetahui manfaat apa yang dapat diperoleh dalam pelaksanaan praktek menelusur literatur (literature searching) bagi mahasiswa Program Studi Pendidikan Dokter FK UGM.

\section{Evaluasi}

Dalam kamus Bahasa Indonesia (1989) disebutkan bahwa evaluasi adalah kegiatan sungguh-sungguh mengamati, mengoreksi, menimbang baik buruknya suatu masalah yang dilakukan dengan dasar-dasar tertentu kemudian memberi penghargaan seberapa besar bobotnya, kualitas, dan kemampuannya. Lasa Hs. (2009) evaluasi adalah pemantuan/ penilaian terhadap kemajuan dan/atau tingkat keberhasilan penyuluhan yang telah dilaksanakan meliputi; persiapan, perumusan materi, strategi pelaksanaan, kendala-kendala, sarana pemecahan masalah, dan masukan untuk penyempurnaan penyuluhan. Berdasar beberapa pendapat tersebut, maka evaluasi suatu proses pengukuran dan penilaian kinerja suatu layanan atau sistem dalam memenuhi tujuan yang telah ditetapkan.

\section{Pendidikan Pemakai Perpustakaan}

Keberadaan perpustakaan sangat diharapkan untuk dapat berperan sebagai agen pengembangan modernisasi masyarakat (Kartosedono, 1995). Kondisi semacam itu hanya bisa ditemui dalam masyarakat yang memiliki budaya baca tinggi. Keberadaan perpustakaan tidak akan berpengaruh dalam masyarakat yang memiliki budaya baca rendah. Perpustakaan sebagai sumber informasi peran yang dilakukan dalam membangun masyarakat literasi, menurut Ratna (2006) dalam Suciati (2007) ada beberapa cara yang dapat dilakukan, (1) pengguna hendaknya diberikan wawasan apa saja fasilitas dan koleksi serta informasi yang tersedia di perpustakaan, (2) 
untuk mengurangi tekanan pengguna dalam menemukan informasi hendaknya perpustakaan selalu menyelenggarakan user education secara berkala, terutama apabila selalu ada penambahan layanan dan fasilitas, (3) pengguna diberikan ketrampilan dalam mengoperasikan sarana-sarana penelusuran baik manual maupun elektronik agar dapat mengakses sendiri dengan efektif, (4) disediakan panduan-panduan yang mudah dipahami pada setiap titik layanan, (5) menyediakan fasilitas yang memadai dengan memanfaatkan teknologi informasi agar lebih efektif dan efesien dalam memanfaatkan informasi, (6) menyediakan koleksi dan informasi yang sesuai dengan kurikulum serta programprogram yang ada di lembaga yang bersangkutan sesuai dengan jumlah dan judul serta senantiasa mengikuti perkembangan koleksi dan informasi terbaru, (7) ditopang dengan jumlah sumber daya manusia yang memadai, berkualitas, professional, dan santun, (8) suasana belajar yang menyenangkan, nyaman, dan aman.

\section{Literasi Informasi di Perpustakaan}

Doyle (1994) dalam Saad (2006), mendeskripsikan information literate:

Person as one who; recognizes that accurate and complete information is the basis for intelligent decision making, recognizes the need for information, formulates questions based on information need, identifies potential sources of information, develops successful search strategies, accesses sources of information including computer-based and other technologies, evaluates information, organizes information for practical application, integrates new information into an existing body of knowledge, uses information in critical thinking and problem.

Hepworth (1999) dalam Irawati (2005) mendefinisikan bahwa information literacy merupakan proses memperoleh pengetahuan terhadap perilaku dan keahlian dalam bidang informasi, sebagai penentu utama dari cara manusia mengeksploitasi kenyataan, membangun hidup, bekerja, dan berkomunikasi dalam komunitas informasi. Dari beberapa definisi tersebut dapat dikatakan bahwa literasi informasi adalah kemampuan seseorang untuk mengenali informasi yang dibutuhkan dan kemampuan untuk menemukan letak informasi tersebut, kemudian mengevaluasi dan juga mampu menggunakan informasi tersebut secara efektif. Hak (2008) mengutip pendapat Rice menjelaskan bahwa pendidikan biasanya selalu mempunyai komitmen untuk memperkuat koleksi perpustakaan dan pengajaran mengenai penggunaannya. Untuk itu dari tahun ke tahun, para pendidik dan pustakawan di berbagai tingkat pendidikan telah memutuskan untuk memberikan keterampilan dasar penelitian perpustakaan bagi setiap siswanya. Salah satunya adalah bagaimana memenuhi kebutuhan cara mencari informasi yang terkini dengan cepat. Para siswa yang tidak memiliki keterampilan ini biasanya dipertimbangkan hanya sebatas untuk mendapatkan pendidikan dalam jangka pendek saja.

Gaunt (2007) menyebutkan bahwa dalam muatan atau materi dalam orientasi perpustakaan, meliputi:

1. Mengetahui bangunan perpustakaan dan pelayanannya;

2. Pengorganisasian berbagai format koleksi yang tersedia (buku, jurnal, photocopy, tipe materi khusus lainnya);

3. Letak koleksi di perpustakaan;

4. Menggunakan alat bantu penelusuran untuk menemukan daftar bacaan;

5. Proses peminjaman, perpanjangan dan pengembalian koleksi dan sistem manajemen alat bantu penelusuran;

6. Menggunakan fasilitas buku dan jurnal elektronik;

7. Menggunakan photocopy/scanning/printing dan peraturannya bagi pengguna.

Melalui orientasi perpustakaan tersebut sehingga penggunan perpustakaan menjadi familiar dengan perpustakaan. Sehingga dalam mencari informasi di perpustakaan tidak akan mengalami kesulitan.

\section{Pelatihan Menelusur Literatur (Literature Searching) di Perpustakaan}

Menurut Lasa Hs. (2009) pemanduan (pelatihan) adalah usaha membantu pemustaka dalam mencari dan menelusur informasi yang mereka perlukan melalui alat temu kembali konvensional maupun teknologi informasi. Pemanduan untuk menelusur informasi ini 
dilakukan oleh perpustakaan dikemas dalam bentukpendidikan pemustaka. Bentukpendidikan pemustaka masing-masing perpustakaan akan berbeda-beda. Hal ini tergantung konsep, metode dan cara dalam melaksanakan pendidikan pemustaka oleh perpustakaan yang disesuaikan dengan pemustakanya. Bentuk pendidikan pemustaka ini umumnya dilakukan dalam kemasan pelatihan dan praktik untuk menelusur literatur di perpustakaan. Moekijat (1994:2) menyatakan bahwa pelatihan berhubungan dengan fakta-fakta, data-data, dan prinsip-prinsip yang diperlukan untuk melaksanakan program pelatihan. Secara rinci komponen-komponen pelatihan terdiri dari:

\section{Pemateri}

Pemateri dalam hal ini dapat dikatakan sebagai instruktur karena menurut Suryawan (2011:2) instruktur memiliki pengertian yang lebih sempit, pola penyampaian instruktur lebih singkat dan biasanya mengarah kepada sistem modul untuk setiap penyampaian pesannya, dikarenakan durasi penyampaian pesan semaksimal mungkin.

Materi atau isi pelatihan adalah pengetahuan, keterampilan, dan sikap yang harus diberikan kepada para peserta untuk mengubah perilaku ke arah tujuan yang telah ditentukan sebelumnya secara sistematik (Moekijat, 1994:3). Materi pelatihan disampaikan secara cermat dan sistematik, apabila isinya tidak sesuai maka dapat dipastikan bahwa hasil pelatihan yang dikehendaki tidak akan dapat tercapai. Materi atau bahan yang perlu disiapkan dalam pelatihan menurut Mujiman (2011:65) di antaranya adalah; (1) tujuan belajar atau silabi, (2) Bahan ajar dan hand out, (3) pustaka pendukung, (4) komputer dengan fasilitas internet, (5) alat-alat bantu belajar.

\section{Waktu Pelaksanaan}

Waktu pelaksanaan pelatihan adalah waktu yang ditentukan selama proses pelatihan berlangsung yang disesuaikan dengan isi pelatihan yang disampaikan (Moekijat, 1994:6). Pada pelaksanaan pelatihan tersebut harus mengikuti rencana yang telah ditetapkan, akan tetapi dalam pelaksanaannya selalu banyak masalah yang perlu dipecahkan dan pemecahan masalah sering berakibat adanya keharusan mengubah beberapa hal dalam perencanaan, perubahan dan penyesuaian apa pun yang dilakukan harus selalu berorientasi pada upaya mempertahankan kualitas pelatihan, menjaga kelancaran proses pelatihan, dan tidak merugikan kepentingan partisipan atau peserta (Mujiman, 2011:65)

\section{Manfaat Praktik Menelusur Literatur Bagi Mahasiswa}

Manfaat praktik menelusur literatur bagi mahasiswa, sebagaimana manfaat dalam pelatihan/training yang diungkapkan UVI Consultant, yaitu:

a. Mengurangi waktu yang digunakan untuk belajar

b. Meningkatkan pengetahuan dan keterampilan

c. Meningkatkan rasa percaya diri

d. Meningkatkan kepuasan kerja

\section{Metode Penelitian}

Metode yang digunakan dalam penelitian menggunakan metode kuantitatif. Adapun populasi dalam penelitian ini adalah Mahasiswa Pendidikan Dokter angkatan 2015/2016 Fakultas Kedokteran Universitas Gadjah Mada sebanyak 273 mahasiswa, terdiri dari mahasiswa kelas Program Reguler sebanyak 182 orang dan mahasiswa kelas Program Internasional 81 orang.

Untuk menentukan sampel digunakan rumus yang dinyatakan oleh Simamora (2004), yaitu:

$$
\text { e = --------- }
$$

Keterangan :

$\mathrm{n}$ = Jumlah sampel

$\mathrm{N}=$ Ukuran populasi

$\mathrm{e}=$ Persen kelonggaran ketidaktelitian karena kesalahan sampel yang masih dapat ditolerir/diinginkan, misal $10 \%$.

Berdasarkan pada rumus tersebut diperoleh jumlah sempel penelitian, sbb:

$$
\text { e = - }
$$


Evaluasi Pelaksanaan Praktik Menelusur ...(Sukirno, Mukhotib)

$$
\begin{aligned}
& \text { e = } \begin{array}{cc}
273 & 273 \\
1+273(0,01) & 2,74
\end{array} \\
& \text { e }=99,63 \text { à } 100 \text { responden }
\end{aligned}
$$

\section{Variabel Penelitian}

Penelitian evaluasi pelaksanaan praktek menelusur literatur (literature searching) pada mahasiswa Program Studi Pendidikan Dokter Angkatan 2015/2016 di Perpustakaan Fakultas Kedokteran Universitas Gadjah Mada yang menjadi variabel penelitian ini merujuk pada pendapat Moekijat (1994) yaitu, (1) Pemateri, (2) Materi dan Metode Pelatihan, (3) Waktu Pelaksanaan. Sedang untuk manfaat merupakan variabel tambahan dengan tujuan akan digunakan untuk mengetahui manfaat bagi mahasiswa. Dari variabel tersebut kemudian dikembangkan dalam indikator-indikator sebagai dasar dalam pembutan kuesioner penelitian.

\section{Analisis Data}

Adapun analisis data yang digunakan dalam penelitian ini adalah analisa deskriptif. Kegiatan menganalisis data ini terdiri dari:

1. Tahap Persiapan

2. Tahap tabulasi

Skala yang digunakan dalam mendapatkan data penelitian adalah skala Likert terhadap masing-masing butir pernyataan dengan rincian nilai masing-masing apabila menjawab:

1. Sangat setuju sekali $=4$

2. Sangat setuju $=3$

3. Setuju $=2$

4. Tidak setuju $\quad=1$

Untuk mengukur masing-masing indikator digunakan analisis univariat dengan menghitung skor prosentase yang didapat, dengan menggunakan rumus perhitungan sebagai berikut:

$$
P=\frac{(\Sigma f x)}{N} \times 100 \%
$$

$\mathrm{P}=$ hasil skor

$\mathrm{fx}=$ nilai skor yang didapat

$\mathrm{N}=$ nilai ideal keseluruhan butir

Nilai $\mathrm{N}$ dihitung dengan mengkalikan jumlah responden dengan nilai ideal jawaban responden yaitu 4, dalam penelitian ini jumlah responden 100.
Jadi nilai $\mathrm{N}$ dalam penelitian ini adalah $100 \times 4$ $=400$

Proses angka-angka hasil perhitungan atau pengukuran dilakukan dengan cara dijumlahkan, dan dibagi dengan nilai idealnya, kemudian diprosentasekan. Hasil prosentase dimaksudkan untuk mengetahui status sesuatu (mengubah data kualitatif menjadi data kuantitatif). Hasil prosentase tersebut ditafsirkan dengan kalimat yang bersifat kuantitatif, yaitu:

1. Baik apabila skor (76-100 \%),

2. Cukup (56-75\%),

3. Kurang baik (40-55\%)

4. Tidak baik (kurang dari $40 \%$ ), (Arikunto, 2002:244).

\section{Hasil dan Pembahasan}

\section{Gambaran Umum}

Proses pembelajaran bagi mahasiswa Program Studi IImu Kedokteran Fakultas Kedokteran UGM dengan menggunakan sistem blok. Dalam proses pembelajaran ini mahasiswa dituntut untuk lebih mandiri dalam proses pembelajaran dengan melibatkan semua bagian. Perpustakaan sebagai bagian dari Fakultas Kedokeran UGM ikut terlibat dalam pendekatan sistem blok ini. Perpustakaan dengan memberikan praktik menelusur literatur (literature searching) yang masuk pada blok A.1. pada topik "Being a Medical Student and Locomotor System". Kegiatan praktik tersebut diselenggarakan di Perpustakaan Fakultas Kedokteran dan disampaikan oleh pustakawan. Adapun tujuan praktik menelusur literatur tersebut, adalah:

1. Mengenalkan keberadaan perpustakaan di Fakultas dan Universitas sebagai penyedia sumber belajar bagi mahasiswa.

2. Mengenalkan beragam literatur sumber belajar yang mendukung studi mahasiswa, baik dalam format cetak, digital, ataupun database journal.

3. Membekali mahasiswa dengan keterampilan dasar penelusuran beragam literatur tersebut dengan memanfaatkan teknologi informasi dan fasilitas lain yang tersedia.

4. Membekali mahasiswa untuk dapat mengevaluasi jenis literatur yang dapat digunakan sebagai referensi. 
Kegiatan praktik menelusur literatur, jadwal dibuat oleh bagian akademik dari Prodi Pendidikan Dokter Fakultas Kedokteran. Jadwal tersebut merupakan rangkaian dari perkuliahan bagi mahasiswa pada Blok A.1.

Gambar 1. Jadwal Praktik Menelusur Literatur Program Reguler

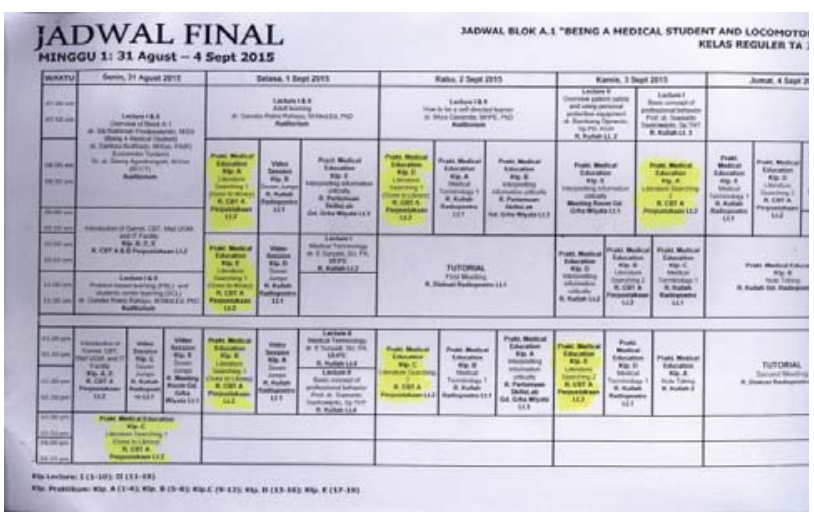

Sumber : Prodi Pendidikan Dokter (2015)

Waktu pelaksanaan praktik menelusur literatur durasi waktunya dibagi dalam 2 sesi, masing-masing sesi selama100 menit. Pelaksanaan praktik menelusur literatur antar sesi pertama dan sesi kedua disampaikan dalam hari yang berbeda. Untuk praktik pada sesi pertama materi yang disampaikan pada mahasiswa tentang:

1. Layanan perpustakaan

2. Sumber-sumber informasi di perpustakaan

3. Strategi menelusur literatur

4. Menelusur literatur digital yang tersedia di perpustakaan

5. Menelusur koleksi cetak di perpustakaan

Sedangkan pada sesi kedua materi praktik menelusur literatur yang disampaikan tentang:

1. Search tool menelusur database online

2. Search pada pubmed

3. Database Clinical Key

4. Database ScienceDirect

5. Sumber-sumber informasi online lain yang free.

\section{Karakteristik Responden}

Jumlah responden yang ditetapkan dalam penelitian sebanyak 100 mahasiswa, baik dari Program Studi Pendidikan Dokter kelas reguler ataupun kelas internasional. Jumlah kuesioner yang disebarkan sebanyak 100. Dari 100 kuesioner yang disebarkan pada mahasiswa, jumlah kuesioner yang kembali sebanyak 99 buah. Berdasarkan data kuesioner penelitian ini ditemukan bahwa paling banyak respondennya adalah perempuan, yaitu 60 orang, sedang laki-laki 39 orang.

Grafik 1. Responden Berdasarkan Jenis Kelamin

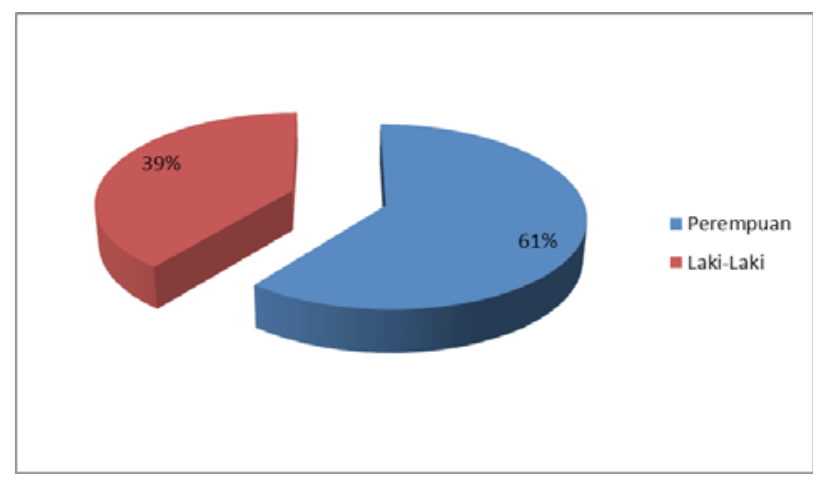

Sumber : Data Penelitian (2015).

Berdasarkan kelas, responden kelas reguler 68 orang mahasiswa sedangkan kelas internasional sebanyak 31 orang mahasiswa.

Grafik 2. Responden Berdasarkan Kelas

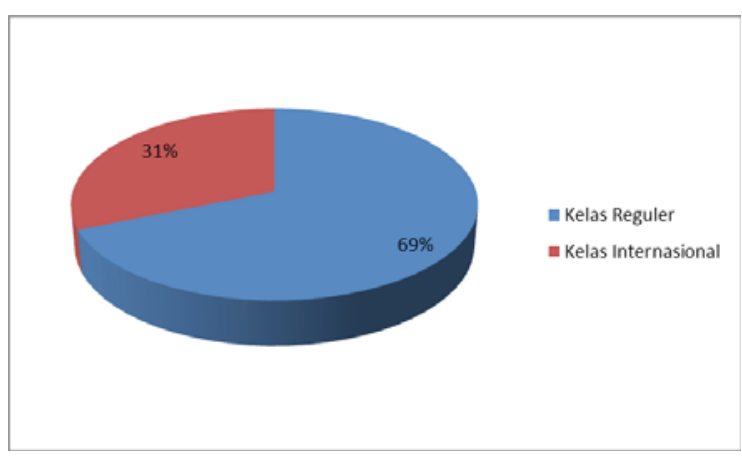

\section{Analisis Evaluasi Pelaksanaan Praktik Menelusur Literatur (Literature Searching) pada Mahasiswa}

Berdasar hasil penelitian dengan menggunakan variabel(1) Pemateri, (2) Materi dan Metode Pelatihan, (3) Waktu Pelaksanaan, dan (4) Manfaat, maka diperoleh nilai skor rata-rata sebagai berikut.

\section{Variabel Pemateri}

Variabel pemateri diuraikan dalam 7 item pernyataan ke dalam kuesioner penelitian. Data penelitian per-item pernyataan adalah sebagai berikut. 
Evaluasi Pelaksanaan Praktik Menelusur ...(Sukirno, Mukhotib)

Tabel 1. Variabel Pemateri

\begin{tabular}{|l|c|c|c|}
\hline No & Pernyataan & $\begin{array}{c}\text { Hasil skor } \\
(\mathbf{\%})\end{array}$ & Kategori \\
\hline 1 & Pernyataan 1 & 88,13 & Baik \\
\hline 2 & Pernyataan 2 & 85,35 & Baik \\
\hline 3 & Pernyataan 3 & 79,29 & Baik \\
\hline 4 & Pernyataan 4 & 90,66 & Baik \\
\hline 5 & Pernyataan 5 & 90,40 & Baik \\
\hline 6 & Pernyataan 6 & 84,60 & Baik \\
\hline 7 & Pernyataan 7 & 83,08 & Baik \\
\hline & Jumlah & 601,51 & \\
\hline
\end{tabular}

Sumber : Data penelitian (2015).

Berdasarkan tabel 1 diperoleh hasil skor rata-rata untuk varibel pemateri sebagai berikut :

$$
\begin{aligned}
\text { Rata-rata skor } & =\text { - } \begin{array}{c}
\text { Hasil skor } \\
\text { Jumlah pernyataan }
\end{array} \\
& =001,51 \\
& =85,93 \%
\end{aligned}
$$

Berdasarkan perhitungan di atas menunjukkan, bahwa variabel pemateri yang dijabarkan dalam 7 pernyataan dikategorikan baik dengan nilai rata-rata skor $85,93 \%$.

\section{Variabel Materi dan Metode Pelatihan.}

Variabel materi dan metode pelatihan diuraikan dalam 8 item pernyataan ke dalam kuesioner penelitian. Data penelitian per-item pernyataan adalah sebagai berikut.

Tabel 2. Variabel Materi dan Metode Pelatihan

\begin{tabular}{|l|l|c|c|}
\hline No & Pernyataan & $\begin{array}{c}\text { Hasil skor } \\
(\mathbf{\%})\end{array}$ & Kategori \\
\hline 1 & Pernyataan 1 & 92,68 & Baik \\
\hline 2 & Pernyataan 2 & 89,65 & Baik \\
\hline 3 & Pernyataan 3 & 91,92 & Baik \\
\hline 4 & Pernyataan 4 & 79,29 & Baik \\
\hline 5 & Pernyataan 5 & 91,41 & Baik \\
\hline 6 & Pernyataan 6 & 90,15 & Baik \\
\hline 7 & Pernyataan 7 & 91,41 & Baik \\
\hline 8 & Pernyataan 8 & 88,38 & Baik \\
\hline & Jumlah & 714,89 & \\
\hline
\end{tabular}

Sumber : Data penelitian (2015).

Berdasarkan tabel 2 diperoleh hasil skor rata-rata untuk variabel materi dan metode pelatihan sebagai berikut :

$$
\text { Rata-rata skor = ----------------------- }
$$

$$
\begin{aligned}
& 714,89 \\
& \text { = --------- } 8 \\
& =89,36 \%
\end{aligned}
$$

Berdasarkan perhitungan di atas menunjukkan, bahwa materi dan metode pelatihan diuraikan dalam 8 yang pernyataan

\begin{tabular}{|c|c|c|c|}
\hline No & Pernyataan & $\begin{array}{l}\text { Hasil skor } \\
(\%)\end{array}$ & Kategori \\
\hline 1 & Pernyataan 1 & 92,68 & Baik \\
\hline 2 & Pernyataan 2 & 89,65 & Baik \\
\hline 3 & Pernyataan 3 & 91,92 & Baik \\
\hline 4 & Pernyataan 4 & 79,29 & Baik \\
\hline & Jumlah & 353,54 & \\
\hline
\end{tabular}
dikategorikan baik dengan nilai rata-rata skor $89,36 \%$.

\section{Variabel Waktu Pelaksanaan}

Variabel waktu pelaksanaan diuraikan dalam 4 item pernyataan ke dalam kuesioner penelitian. Data penelitian per-item pernyataan adalah sebagai berikut.

Tabel 3. Variabel Waktu Pelaksanaan

Berdasarkan tabel 3 diperoleh hasil skor rata-rata waktu pelaksanaan pelatihan sebagai berikut :

$$
\begin{aligned}
\text { Rata-rata skor } & =\text {------------------- } \\
& \text { Jumlah pernyataan } \\
& =353,54 \\
& 4 \\
& =81,19 \%
\end{aligned}
$$

Berdasarkan perhitungan di atas menunjukkan, bahwa waktu pelaksanaan diuraikan dalam 4 yang pernyataan dikategorikan baik dengan nilai rata-rata skor $81,19 \%$.

\section{Variabel Manfaat}

Variabel manfaat diuraikan dalam 5 item pernyataan ke dalam kuesioner penelitian. Data penelitian per-item pernyataan adalah sebagai berikut. 
Tabel 4. Variabel Manfaat

\begin{tabular}{|l|l|c|c|}
\hline No & Pernyataan & $\begin{array}{c}\text { Hasil skor } \\
(\mathbf{\%})\end{array}$ & Kategori \\
\hline 1 & Pernyataan 1 & 91,67 & Baik \\
\hline 2 & Pernyataan 2 & 91,16 & Baik \\
\hline 3 & Pernyataan 3 & 90,91 & Baik \\
\hline 4 & Pernyataan 4 & 84,85 & Baik \\
\hline 5 & Pernyataan 5 & 82,32 & \\
\hline & Jumlah & 490,91 & \\
\hline
\end{tabular}

Sumber : Data penelitian (2015).

Berdasarkan tabel 4 diperoleh hasil skor rata-rata untuk variabel manfaat sebagai berikut:

$$
\begin{aligned}
\text { Rata-rata skor } & =\text { Hasil skor } \\
& \text { Jumlah pernyataan } \\
& =\begin{array}{c}
490,91 \\
5 \\
\end{array} \\
& =88,18 \%
\end{aligned}
$$

Berdasarkan perhitungan di atas menunjukkan, bahwa manfaat diuraikan dalam 5 yang pernyataan dikategorikan baik dengan nilai rata-rata skor $88,18 \%$.

Berdasarkan rata-rata skor masing-masing variabel sebagaimana dalam tabel di atas, maka analisis evaluasi pelaksanaan praktik menelusur literatur (literature searching) pada mahasiswa

\begin{tabular}{|c|c|c|c|}
\hline No & Variabel & $\begin{array}{c}\text { Hasil } \\
\text { skor (\%) }\end{array}$ & Kategori \\
\hline 1 & Pemateri & 85,93 & Baik \\
\hline 2 & $\begin{array}{l}\text { Materi } \\
M \text { dan } \\
\text { Pelatihan. }\end{array}$ & 89,36 & Baik \\
\hline 3 & $\begin{array}{l}\text { W a } \quad k \quad t \quad u \\
\text { Pelaksanaan }\end{array}$ & 81,19 & Baik \\
\hline 4 & Manfaat & 88,18 & Baik \\
\hline \multicolumn{2}{|c|}{ Jumlah } & 344,66 & \\
\hline
\end{tabular}
dapat dilakukan sebagai berikut.

Tabel 5. Evaluasi Pelaksanaan Praktik Menelusur Literatur (Literature Searching) pada Mahasiswa

Sumber : Data penelitian (2015).

Berdasarkan tabel 5 diperoleh hasil skor rata-rata sebagai berikut:

$$
\begin{aligned}
& \text { Hasil skor } \\
& \text { Rata-rata skor = ------------------------ } \\
& =\frac{344,66}{4} \\
& =86,17 \%
\end{aligned}
$$

Berdasarkan perhitungan di atas menunjukkan, bahwa evaluasi pelaksanaan praktik menelusur literatur (literature searching) pada mahasiswa dengan keempat variabel dikategorikan baik dengan nilai rata-rata skor $86,17 \%$.

\section{Kesimpulan}

Penelitian evaluasi pelaksanaan praktik menelusur literatur (literature searching) pada mahasiswa Program Studi Pendidikan Dokter angkatan 2015/2016 di Perpustakaan Fakultas Kedokteran Universitas Gadjah Mada, berdasarkan hasil dan pembahasan dalam penelitian ini dapat disimpulkan baik, dengan nilai rata-rata skor $86,17 \%$. Hasil ini diperoleh dari semua variabel penelitian memperoleh kategori baik, yang terdiri; (1) pemateri, (2) materi dan metode pelatihan, (3) waktu pelaksanaan, dan (4) manfaat.

\section{Saran}

Berdasarkan hasil dan pembahasan dalam penelitian ini, maka yang dapat peneliti rekomendasikan berdasarkan dari usulan atau saran dari responden, adalah sebagai berikut:

1. Pemateri saat menyampaikan materinya dibuat lebih menarik dengan lebih interaktif dan diperbanyak untuk praktik menelusur.

2. Jadwal praktik menelusur literatur dibuat tidak sore hari, sebab mahasiswa sudah merasa lelah sehingga kurang optimal dalam menerima materi praktik.

3. Fasilitas untuk praktik menelusur literatur perlu ditingkatkan utamanya akses internet sehingga saat mengunduh artikel full text tidak terasa lambat.

\section{Daftar Pustaka}

Anonim. 1989. Kamus Besar Bahasa Indonesia. Jakarta: Balai Pustaka.

Arikunto, Suharsimi. 2000. Manajemen Penelitian. Jakarta: Rineka Cipta

Departemen Pendidikan dan Kebudayaan. 1990. Kamus Besar Bahasa Indonesia. Jakarta: Balai Pustaka.

Gaunt, Jessica. 2007. Handbook for Information Literacy Teaching. Diunduh dari http://www. cardiff.ac.uk/insrvstaff/projectandworking/ infoliteracy/conferences/lilac/lilac07/ 
Hak, Ade Abdul. 2008. Pendidikan Pemakai: Perubahan Perilaku Pada Siswa Madrasah Dalam Sistem Pembelajaran Berbasis Perpustakaan. Diunduh dari http://abdulhak. multiply.com/journal/item/9/PENDIDIKAN_ PEMAKAI

Irawati, Indira. 2005. Penguasaan Information Literacy Mahasiswa Program Studi IImu Perpustakaan, Skripsi Fakultas IImu Pengetahuan Budaya, Universitas Indonesia.

Kartosedono, S. 1995. Perpustakaan sebagai Lembaga Pendidikan dan Sarana Mencerdaskan Masyarakat Bangsa . Media Pustakawan 2(20):4-5.

Lasa Hs. 2009. Kamus Kepustakawanan Indonesia. Yogyakarta: Pustaka Book Publisher.

Moekijat. 1994. Metode Riset dalam Pelatihan. Bandung: Mandar Maju.

Mujiman, Haris. 2011. Manajemen Pelatihan Berbasis Belajar Mandiri. Yogyakarta: Pustaka Pelajar.

Sastrowiyoto, Soenarto. 2003. Menyongsong Pelaksanaan PBL Penuh (Sosialisasi dari Sisi Lain). Media EFKAGAMA, 9(3):1-2.

Sanderson, Ralph. (2006). The Role of Developed Countries to Support Information Literacy in Developing Countries. Denpasar: Kongress IPI Ke-X.

Suciati, Uminurida. 2007. Manfaat Information Literacy (Literasi Informasi) bagi Pustakawan. Media Informasi Vol. XVI, No.2, p. 10-17.

Uvi Consultan. 2015. Manfaat Training Bagi Karyawan Perusahan. Diunduh dari http:// uvi.co.id/manfaat-training-bagi-karyawanperusahaan/ 